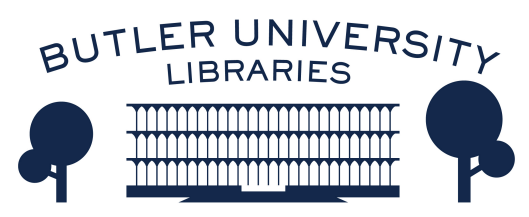

Journal of Hindu-Christian Studies

Volume 7

Article 10

January 1994

\title{
Hindu-Christian Studies as a Necessary Luxury in the Context of Today's Pluralism
}

Francis Clooney

Follow this and additional works at: https://digitalcommons.butler.edu/jhcs

Part of the Religion Commons

\section{Recommended Citation}

Clooney, Francis (1994) "Hindu-Christian Studies as a Necessary Luxury in the Context of Today's Pluralism," Journal of Hindu-Christian Studies: Vol. 7, Article 10.

Available at: https://doi.org/10.7825/2164-6279.1098

The Journal of Hindu-Christian Studies is a publication of the Society for Hindu-Christian Studies. The digital version is made available by Digital Commons @ Butler University. For questions about the Journal or the Society, please contact cbauman@butler.edu. For more information about Digital Commons @ Butler University, please contact digitalscholarship@butler.edu. 


\title{
Hindu-Christian Studies as a Necessary Luxury in the Context of Today's Pluralism
}

\author{
Francis Clooney, S.J. \\ Boston College
}

DURING 1992-3 I had the good fortune to live in Madras and spend the year reading both Tiruvaymoli, the Tamil religious classic composed by Satakopan of Kurukur (8th century $\mathrm{CE}$ ), and also large sections of the early commentaries on it, particularly the great Itu of Nampillai (14th century). For the purpose of this study I met regularly with several learned teachers of the Srivaisnava tradition, with one of them for about two hours a day. Though I had studied these texts on and off during the previous ten years, this period of prolonged and intense study immeasurably deepened my knowledge of the texts. The environment was ideal for my research, and I was able to make satisfying progress on several projects.

The year was also the occasion for a broadening of the context of my research. The Srivaisnava community flourishes in Madras and in some smaller towns of Tamil Nadu, and there were always lectures, festivals and other special events to attend, as well as the daily opportunity to visit temples where I could observe the ordinary worship of Srivaisnavas. In Madras and other centres of Srivaisnavism I visited, I was almost always well and warmly received by members of the community, and in most places extraordinary hospitality was extended to me. I was able to see in vivid detail what it means to live according to Tiruvaymoli - as the classical commentators urged - and thus to dwell even today in a world formed by a sacred text; it was to some extent like looking into an unevenly polished mirror which showed me something of the patterns of my own tradition, and also things even in myself I could see for the first time only here. Likewise, larger issues of community and commitment, faith and understanding, came home to me in a particularly vivid fashion, at certain moments of real encounter and understanding.

The year was a very fine one, and it confirmed my professorial view that there is no substitute for intensive research. Though my daily routine would suggest to the observer that research is unremarkable, routine and unlikely to be noticed much (at least in the short term), I am all the more convinced that this research is essential to a measured, enduring and fruitful response to the quickly evolving situation of religious pluralism throughout the world. If we are to understand and appropriate in an integral fashion what is happening today, this requires a retrieval of the popular and elite classics of the Christian and Hindu religious traditions, and on that basis the articulation of our shared future.

Nevertheless, travel, learning and living abroad for a year in this way also tend to make evident just how large the world is. India, though too big to fit easily under the label of "microcosm", is alive - dying, being reborn - according to the best and worst of the changes familiar to us at the end of the 20th century; even in the midst of the still relatively polite crowds of Madras' Anna Salai or Marina Beach or Parry's Corner, again and again I became part of swelling and shifting crowds of Indians of every sort and purpose, and yet at the same time - certainly by face and complexion and accent, probably by manners and style and other more subtle differences - marginal to that flow, a temporary observer witnessing 
a great urban vitality. Cycling back and forth between my books and my teachers, I could not help but see, immediately, vividly, how the traffic flowed around me, how all of this was not going to be directly or in important ways instigated or impeded by the work of scholars engaged in the study of Hindu and Christian texts. Everywhere one goes one can see how very basic ideas about religion and being religious are changing today, and what is happening outstrips our ability to explain it or even talk about it; we are always catching up. One can argue that such changes are in large part features of ordinary, real-life pluralism - as ancient Indian religious movements undergo yet further revivals, as modernization (which in some ways is still justly called "westernization") continues to change India in everything from political styles to the way people spend their leisure time to how they locate their lives within religion (or vice versa), as a new immigration makes Indian religious groups a vital presence in the West, as the West rethinks and revises yet again its attitudes toward its own religious heritage, as Western academe is increasingly marked by a fundamental - foundationless pluralism of perspectives on just about every issue. Pluralism happens, whether religious scholars are doing research or not; research is not the linchpin of progress in the interreligious realm, it is a luxury, extra and non-essential. In my view, though, it can be termed a necessary luxury. Let us first examine four reasons why it is a luxury.

\section{The Luxury of Hindu-Christian Studies in the Context of Today's Pluralism}

First, the phenomenon of the Hindu and the Christian studying each other's beliefs, texts, images, practices, etc. - "Hindu-Christian studies" for short - is clearly a luxury with respect to the state of learning within these two (sets of) traditions today. For every two people in Madras who applauded my effort to become deeply familiar with a classic Hindu tradition, there was at least one -
Hindu or Christian - who would (also) observe how hard it is today just to get people to study their own religious traditions. Some were quick to insist that it is more surely important for Hindus to study their Hindu traditions, or Christians their Christian traditions - before moving on, at some later time, eventually, to learn other people's traditions. Some would hypothesize, with familiar modesty, that my kind of study of the "other" might be possible in the West, but not in modern India, where even the basics are being quickly forgotten.

It seems to me that this reaction is in part indicative of frustration and perhaps fear in reaction to the religious changes whirling about us. One hovers on the edge of the whirlwind and tries first to get one's own stance firm and fixed before venturing even one further step forward. (It has also occurred to me that perhaps this idea of the decline of religious learning is in part a contemporary myth, built in part on a rise in literacy and documentation, heightened expectations about our potential, as well as the perennial human tendency to dwell on the miseries of our particular time and place.) Nonetheless, the reaction is indicative of a basic, persistent priority: it is necessary to know one's own tradition, one's roots and foundations, first. From this perspective, whatever else one might later learn is additional, a luxury left for the few unusual people.

Second, Hindu-Christian studies are a luxury because they are extra, often unexpected, out of place, unconnected with the rest of "being a Hindu" or "being a Christian". I was aware - often made aware - of just how odd my commitment to the study of Tiruvaymoli and the commentaries seemed to those around me. If it was rare enough to be able to devote oneself for a year to the study of texts, it was rarer still to see someone come from the West to read these particular texts. Many of the people I worked with most closely, including my teachers, had previously had little or no 
contact with foreigners, and to my knowledge none had ever met a foreigner who wanted to read the Itu thoroughly and in detail. Many were impressed, and given to speculation over the reasons why I had this interest.

Some felt simply that I had been summoned by the grace of Lord Visnu, to learn these treasures and bring them back to the west; or that I had been a Srivaisnava in a previous birth, and by some vague instinct had managed to return to south India in search of my lost heritage. Likewise, some Christians just assumed that I was doing the kind of pre-evangelization Jesuits had always engaged in, or simply engaging in a postVatican II well-meaning benevolence toward people of other religions. Some were more sceptical, even when friendly, and as it were held their breath, waiting to see just what this Catholic priest (I had made no secret of my identity) would do with what he was so diligently learning: after all, Jesuits had always been studying Hindu texts, and in the end even the best research usually came to conclusions confirming the Christian worldview in some predictable or novel way.

There were a few - among the pious, among impatient people of action - who saw me just as one more western scholar with an essentially foreign, pedantic agenda: jetting in to sift through other people's religious heritage, to submit it to one or another trendy methodology derived in the west and, inevitably, to show how the tradition's view of things did not fit together, was not historically sound, etc., and then, after a few farewells, heading home to write about "the Hindus" in a way that would reflect little of what the real India is like.

What these divergent views had in common was that almost no one among the Hindus I knew seemed to entertain the views that I generally, though not with total consistency, have tended to hold about myself: first, that I have a great intellectual curiosity and a deep desire to know - and that Tiruvaymoli and the Itu are extremely interesting, worth knowing - and second, that it is my Roman Catholic faith itself that pushes me to seek to know everything that truly belongs to God in order to know God and so to delve deeply into Srivaisnava learning which, without the slightest doubt, is of God. These are theoretical points, but certainly existential as well, and the dynamics of this learning are essentially religious. Anyone familiar with devotional literature in any tradition knows the theme of captivation, how one can get more than one has bargained for when one takes religion seriously, getting drawn into it, never getting enough of it. Even someone else's religion can become vitally, urgently, too alive for a person who might initially just have been curious.

In any case, I fear that at the deeper level I had not communicated well enough with either Hindu or Christian friends about the real purposes for what we do. Why I was in Madras was not adequately clear to the people I was working with, a year was not long enough for that kind of conversation to come to the fore.

Third, my work had to be counted a luxury in part for the simple fact that few Hindus have seemed to experience any reciprocal, comparable urgency: my "necessity" was for almost everyone a luxury which did not bear reciprocity. During my trips to India, and certainly during this most recent one, I did not meet, or even hear of, a Hindu doing, or wanting to do, the converse of my project: to undertake the task of learning, let us say, classical Greek in order, let us say, to study some great treatise of the Christian Patristic period. In the midst of today's flourishing pluralism, serious research about the "other's religion" is still primarily, even if not exclusively, a Christian and western project. Hence, in my opinion, the intellectual exchange among Hindu and Christian scholars today - as for a number of centuries, as a matter of fact - has on this account remained relatively impoverished, skewed and impeded by differences in understanding and interest as to what is 


\section{Francis Clooney}

important. If this exchange and cooperation is to flourish, there needs to be a great number of "mirror projects": if I study Tiruvaymoli, there needs to be a Hindu studying the Psalms in Hebrew; if I study the Itu, there needs to be someone studying in Latin Augustine's commentary on the Psalms, etc. Only then, if Hindus show more interest in studying the Christian tradition for themselves, will the luxury of cross-religious study become less susceptible to the suspicion that it is not really a luxury, but part of some agenda peculiar to the Christian West.

Finally, we must admit that HinduChristian studies are a luxury from a purely economic perspective - and this point may have struck many readers first of all. Even Westerners of modest means who go to India find themselves to be rather wealthy upon arrival there, "rich (even if not 'ugly') Americans". Last year's visit - like my previous visits - was marked in part by the signal fact that it was economically viable for me to choose to visit India. I could travel, and I could assemble the materials needed for research. I had access to the necessary texts as well as to the required secondary literature back home, could purchase any book I needed, and had the "necessary" resources for word processing, xeroxing, travel, postage, and even the occasional fax back home. Such basic resources were not easily available to the Hindu scholars I studied with; they were always short on resources, hampered by inadequate library facilities, and severely constrained in their ability to travel; even basic primary sources were often unavailable, or only in crumbling editions printed 50 or 60 years ago.

As a scholar, I therefore had so much available to me that enabled me to do scholarly work at a level expected in the west; even if in important ways I still knew relatively little about the materials I was studying, I maintained a distinct advantage in the academic world over people who knew much more about Srivaisnavism, and
I am much more likely than they are to publish what I know. When research projects are inaugurated, we must admit that the playing field is not level, that the rules and expected final score are never quite fair - as if the issue were not Hindu-Christian studies, but almost always "Christian studies of the Hindu".

\section{Making a Place for the Luxury.}

What then shall we make of all this? It is clear that even if we want to affirm that Hindu-Christian studies are invaluable, there must be an environment in which it makes sense to see this research as a necessary luxury, something which does not occur on the grounds of some immediate necessity for it is obvious that most people do not see any such necessity, and I do not wish to appeal to the wisdom of the selecti quidem but which is truly extra, superfluous, excessive, something on which we can lavish some of our scant resources, and as a luxury we stand ready to defend.

We must foster a conversation on the points I have been identifying (and others too), to make sure that our individual research is accompanied by larger cooperative ventures in conversation which nurture the environment in which scholars, Hindu and Christian both, can regularly respond to the situation of pluralism by a serious study of each other's texts and, on that basis, engage yet again in a further, real and deep conversation informed by shared knowledge and differing perceptions. I do not have any ready program to propose here, but conclude simply with four suggestions corresponding to my previous points.

First, we might as well admit that such Hindu-Christian study is not any tradition's primary necessity. The study of religious traditions other than one's own will for a long time continue to occur in the midst of a rapidly changing world in which all kinds of serious religious people will be concerned primarily with the preservation and fostering of their own specific religious heritages, as older mechanisms of tradition continue to 
break down. This is not a bad concern in itself; indeed, unless traditions maintain and renew themselves, there will be increasingly less scope for cross-religious study! Studies by Hindu and Christian scholars of each other's traditions must proceed only in constant dialogue with those theologians who study only their own traditions.

Second, since Hindus - and many Christians, in India and the West - do wonder why some Christians show such an extraordinary interest in all things Hindu, it is fair enough to expect that we who are thus engaged craft more adequate responses to their (implicit) questioning. If we really believe that our work is neither simply missionary nor simply the scientific study of religion, but rather includes another spiritual dimension, we need to be able to show how in our case at least western-style scholarship does have a constructive faith aspect. We need to be able to indicate, much more forthrightly than we usually do, the spiritual validity of our research. Likewise, if some of us think of ourselves as Christian theologians even when we are studying about Hinduism, and if this self-image is accurate, we need to review more closely the history of Christian scholarship about India, catalogue once again its obvious and more subtle prejudices, and examine honestly whether some of the same tendencies are still operative today, even implicitly, in the questions we ask, the criteria we rely on. We need either to admit that ultimately we do have evangelical motives for what we do, or to explain more persuasively than we usually do how our work is Christian theology in some new sense - and what this novelty is supposed to mean.

Third, I must venture to address the Hindu readers of this journal. Scholars in the West do wonder what is going on among Hindu scholars today, what is new and exciting within the traditions of Hinduism; or, if the "new" and the "exciting" are not the right categories, then at least what it is that engages the best minds of young Hindu scholars today, what is the nature of that contemporary Hindu scholarship (in Sanskrit or a vernacular or English) which is maintaining - while yet renewing - its Hindu character by informing it with knowledge about a wider world, particularly this world in which many religions have flourished for millennia, and still do. And why not hear it right here, in HinduChristian Studies?

Since Hindu scholars surely do have ideas about the Bible and about Christianity, and on occasion are not hesitant to speak about them, it is possible to ask further about when it is that we can expect to see some new input here, an appropriation of Christianity that is not based largely on how Western Christians have chosen to present themselves in one or another missionary or colonial guise or on how things were said a century ago; e.g., when will a few young Hindu scholars study Athanasius and Augustine, Aquinas, Calvin, Barth, Rahner? Are there deeper reasons which make it so rare that Hindu scholars study Christianity seriously? If it is really not of interest to Hindu scholars to study the Christian tradition in any depth, would this mean that there really are Christian and Western roots undergirding cross-religious study, in general?

Fourth, let us return to the issue of the economics of this research. At least we need to identify this disparity of resources as a very major factor in the slow progress of collaborative and mutually nourishing Hindu-Christian studies. It is neither right nor practical to postpone examining closely and forthrightly the impact on HinduChristian studies of the vast disparity in resources available to the scholars (potentially) involved. If, as is surely true, we expect scholars to be conversant about the discussions carried on in academic journals, to use the best critical editions and supporting materials, and we increasingly expect scholars of religion to do "on-site" research where the most pertinent and valuable resources are to be found - then on all these counts money matters: it is expensive to be able, personally or even 


\section{Francis Clooney}

through a nearby library, to have access to the publications, to take the postgraduate courses, to be able to travel for shorter or longer periods of time to either great Hindu or Christian centres of learning. Western scholars can manage these things, Indian scholars find it much harder, often impossible. Somehow, there must be more funding, through academic institutions or funding agencies, to generate more balanced, reciprocal projects of research, particularly in those areas of religious and philosophical studies which in every culture tend to be the ones which most often lack necessary funding. As a starting point, there could be specific collaborative projects engaging scholars in India and the West who as far as possible share scholarly resources which will facilitate their work. In the long term, too, one has to wonder (and worry) about the job market; we know how the strong departments of the humanities and of religion in the West make it possible for scholars here to make a living doing what they love to do, and we know about the scarcity of teaching positions in religious studies in India. In any case: if Hindu scholars remain in the position of not being able to afford to do what we and they both expect, if they cannot afford to study the Christian tradition, then the call for such projects may remain more an embarrassment than a productive setting of directions.

\section{Toward a Necessary Luxury}

To admit that Hindu-Christian studies are not a necessity is to admit that the world goes on around us, that the exciting and important encounters of religious peoples are taking place at an increasingly fast pace whether scholars notice this or not, admit it or not; it is, of course, also to admit that this is yet one more thing which is strictly speaking religiously unnecessary for the individual believer (who can get by without most things). In accounting for the way things are and thus sharply diminishing the rhetoric by which scholars often surround what they happen to do with the aura of inevitability, we also achieve the possibility of a more precise sense in which this luxury is a necessary, worthwhile excess.

When we call these studies a necessary luxury, we are at least committing ourselves to a response along the lines I have outlined above: what is recognized as merely extra is in an important sense also required. To regard these studies as a necessary luxury is to insist on the value of research and reflection as integral to the completion of the most important human endeavours, as such studies give a form and voice to what is going on around us; it is to insist that the reasonable and prudent boundaries of one's faith are there to be transgressed; it is to venture to preserve and protect one's faith by forever seeking what is outside it, by forever inviting outsiders in; it is sharing what one has - money, time, home, ideas, hopes: and all of this when one does not have to, when it is a luxury.

We are therefore also pointing to a deeper, more consciously, freely religious level of pluralism - where abundance, flourishing, holy excess, accompanies what is occurring "naturally", stretching it beyond its anticipated limits and boundaries. In life, the necessary is accompanied by the freely chosen; the business relationship by friendship; a required collaboration by falling in love. In the midst of today's necessary and inevitable pluralism, these Hindu-Christian studies can function as one of the forms of this deeper friendship and falling in love, where the inevitable and necessary pass over into a freely chosen, liberally indulged and pursued commitment to take each other seriously and, as the studies proceed, into relationships of heart and mind which are religious in themselves. When Hindus and Christians have met, and met repeatedly, this encounter can find ways to be more than grudging, to become abundant and overflowing; then the necessary luxury of Hindu-Christian studies achieves its modest and therefore more essentially religious position in the context of today's necessary pluralism. 